\title{
Manajemen Kemitraan SMK Dengan Dunia Usaha dan Industri Untuk Meningkatkan Kompetensi Lulusan SMK
}

\author{
Ai Asiah \\ Uninus Bandung \\ aiasiah12@gmail.com
}

\begin{abstract}
This study has the objective to describe: (1) the relationship management and school linkages in SMK; (2) forms of collaboration; (3) enabling; (4) inhibiting factors of collaboration; (5) how to overcome obstacles in collaboration. This type of research is descriptive qualitative research method of data collection using interviews, observation and documentation. Data were analyzed with methods of analysis of data reduction, data presentation, drawing conclusions and preparing recommendations. The results of this study are: (1) the management of school partnerships with DUDI in SMK 1 Panjatan majoring Pharmacy; (2) The form of collaboration; (3) The supporting factors of the partnership include the shared vision and mission, the mutual interests of the school and DUDI, the ability and support of the school committee, the availability of facilities and infrastructure; (4) The inhibiting factors of the partnership include differences in school orientation and DUDI, the productive teachers is lacking, limited time and resources, distance schools that are far away, the lack of DUDI around the school, DUDI capacity to accommodate internship students. (5) How to overcome the barriers to establish communication, exploring sources of funding, expanding cooperation, conducting rolling for apprentices.
\end{abstract}

Keywords: Management, Collaboration, DUDI, Student Competence

\section{ABSTRAK}

Tujuan penelitian ini untuk mengetahui: (1) manajemen hubungan kemitraan sekolah dengan Dunia Usaha dan Dunia Industri (DUDI) di SMK; (2) bentuk kemitraan; (3) faktor pendukung; (4) penghambat kemitraan; (5) cara mengatasi hambatan dalam kemitraan. Jenis penelitian yang digunakan adalah deskriptif kualitatif. Teknik pengumpulan data berupa wawancara, observasi, dan studi dokumentasi. Teknik analisis data menggunakan metode analisis reduksi data, penyajian data, penarikan kesimpulan dan menyusun rekomendasi. Hasil penelitian menunjukkan: (1) manajemen kemitraan sekolah dengan dunia usaha dan dunia industri di SMK Negeri 1 Panjatan jurusan Farmasi Klinis; (2) Bentuk kemitraan berupa penyesuaian kurikulum dengan DUDI, magang, penguji kompetensi kejuruan, bakti masyarakat, penyerapan tenaga kerja oleh DUDI dan kunjungan industri; (3) Faktor pendukung kemitraan berupa kesamaan visi dan misi, kepentingan sekolah dan DUDI yang saling menguntungkan, kemampuan dan dukungan dari komite sekolah, ketersediaan sarana dan prasarana; (4) Faktor penghambat kemitraan berupa perbedaan orientasi sekolah dan DUDI, jumlah guru produktif kurang, keterbatasan waktu dan sumber dana, jarak tempuh sekolah yang jauh, minimnya jumlah DUDI, dan kapasitas DUDI. (5) Cara mengatasi hambatan dengan menjalin komunikasi, menggali sumber dana, memperluas jaringan kemitraan, melakukan rolling bagi siswa magang.

Kata Kunci: manajemen, kemitraan, DUDI, kompetensi lulusan maksimal 4 kata kunci 


\section{Pendahuluan}

Memasuki era global, dunia pendidikan di Indonesia menghadapi tantangan yang semakin berat serta kompleks. Perkembangan dunia pendidikan saat ini sedang memasuki era yang ditandai dengan gencarnya inovasi teknologi, sehingga menuntut adanya penyesuaian sistem pendidikan yang selaras dengan tuntutan dunia kerja. Peranan sector pendidikan dalam mempersiapkan sumber daya tersebut tidak dapat diabaikan. Program pendidikan harus berorientasi pada kebutuhan pasar kerja. Demikian pula produk yang dihasilkan oleh dunia usaha merupakan konsumsi masyarakat luas. Dengan demikian proses pendidikan dan pelatihan akan memberi arti pada pencapaian tujuan pendidikan nasional.

Pendidikan kejuruan menurut Evans dalam Murniati (2009:1) adalah "bagian dari sistem pendidikan yang mempersiapkan seseorang agar lebih mampu bekerja pada suatu kelompok pekerjaan atau satu bidang pekerjaan daripada bidang-bidang pekerjaan lainnya". Dengan demikian maka pendidikan kejuruan dan/atau vokasi dalam system pendidikan nasional diharapkan mampu mempersiapkan dan mengembangkan sumber daya manusia (SDM) yang mampu bekerja secara profesional dibidangnya, sekaligus berdaya saing dalam dunia kerja, terutama dalam menghadapi tuntutan Masyarakat Ekonomi Asia (MEA). Pendidikan kejuruan yang disesuaikan dengan penyediaan lapangan kerja merupakan kebutuhan sangat mendasar dan pokok dalam proses pembangunan nasional Indonesia.
Fakta

menunjukan

bahwa

pembangunan pendidikan masih dihadapkan pada besarnya angka pengangguran akibat adanya ketimpangan antara output pendidikan dengan lapangan kerja dan ketersediaan lapangan kerja formal. Yang mana jumlah angkatan kerja dari tahun ke tahun terus bertambah dan tidak diimbangi ketersediaan lapangan kerja. Berdasarkan laporan Badan Pusat Statistik (BPS) bulan Agustus 2017, jumlah tingkat pengangguran terbuka (TPT) di Indonesia mencapai 5,5\% dari 121,02 juta penduduk yang bekerja. Kepala BPS Suryamin mengatakan bahwa, jumlah tersebut meningkat 90 ribu orang dari penghitungan terakhir yang dilakukan Februari 2016.

Dilihat dari tingkat pendidikan, TPT untuk Sekolah Menengah Kejuruan (SMK) paling tinggi diantara tingkat pendidikan lain, yaitu sebesar 11,41 persen. Tingginya tingkat pengangguran yang berasal dari lulusan SMK atau pendidikan kejuruan tersebut, pada umumnya muncul karena adanya ketidaksesuaian antara output dari sekolah yang tidak dapat memenuhi kebutuhan dunia usaha dan dunia industri yang senantiasa terus berkembang. Oleh karena itu maka diperlukan upaya peningkatan terhadap kompetensi lulusan SMK sehingga mereka lebih siap untuk memasuki dunia kerja.

Napitupulu (2012) mengatakan, mulai tahun 2013 pemerintah membuat program pendidikan menengah universal, dimana Kementerian Pendidikan dan Kebudayaan akan memperkuat pendidikan vokasi di jenjang pendidikan menengah. Target pada tahun 2015 perbandingan SMA dan SMK diharapkan mencapai $45 \%$ dan 55\%, hingga tahun 2020 ditargetkan 
diperoleh perbandingan $40 \%$ dan $60 \%$ dari sekolah yang ada saat ini yang baru mencapai $51 \%$ dan $49 \%$. Hal tersebut diperkuat dengan adanya Instruksi Presiden Nomor 9 Tahun 2016 tentang Revitalisasi Sekolah Menengah Kejuruan dalam rangka peningkatan kualitas daya saing SDM Indonesia. Dengan demikian penambahan jumlah SMK menjadi agenda penting Kementerian Pendidikan dan Kebudayaan, sehingga saat ini masing-masing SMK harus mampu mempertahankan mutunya dengan menghasilkan lulusan yang kompeten dan siap bersaing dalam dunia kerja.

Salah satu upaya dalam meningkatkan kualitas atau mutu dari lulusan pendidikan kejuruan adalah adanya penetapan kebijaksanaan link and match, dimana pihak sekolah khususnya pendidikan menengah kejuruan memungkinkan untuk bekerjasama dengan Dunia Usaha dan Dunia Industri (DUDI) dalam membina dan mengembangkan potensi peserta didik di lapangan. Hubungan yang sinergis antara sekolah dan DUDI merupakan kondisi yang sangat membantu dalam upaya menciptakan proses yang benar-benar efektif bagi anak didik. Bekal keterampilan bagi anak didik adalah hal utama yang harus menjadi program sekolah dan DUDI. Bekal keterampilan yang aplikatif adalah pembekalan yang terkait erat dengan kebutuhan masyarakat. Jika institusi sekolah dan DUDI memberikan pembekalan keterampilan sesuai dengan kebutuhan masyarakat, tentunya lulusan sekolah dapat diserap secara maksimal oleh DUDI. Kondisi seperti inilah yang sebenarnya kita harapkan dari proses pendidikan dan pembelajaran di sekolah kejuruan.

Menurut Moss (1984:71) kerjasama antara sekolah dengan dunia usaha dan dunia industri merupakan suatu kesatuan usaha yang terus-menerus untuk mencapai tujuan bersama dengan membagi wewenang dan tanggung jawab. Kerjasama ini bukan karena hanya sekedar sebagai pendukung tetapi kerjasama dalam arti kemitraan yang sejajar (partnership). Sekolah perlu melakukan manajemen kemitraan dengan dunia usaha dan dunia industri sebagai salah satu bentuk pengelolaan manajemen yang saling terkait antara dua institusi dalam melaksanakan pendidikan dan pelatihan yang saling mengisi, saling membutuhkan, dan saling menguntungkan di dalam melakukan program kemitraan yang direncanakan.

Manajemen kerjasama atau kemitraan di sebuah sekolah dapat ddiartikan sebagai sebuah proses yang khas dan terdiri dari tindakan-tindakan yang melibatkan fungsi-fungsi manajemen seperti perencanaan (planning), pengorganisasian (organizing), pelaksanaan (actuating), dan evaluasi/pengendalian (controlling) yang dilakukan untuk mengatur suatu hubungan antara lembaga pendidikan dan DUDI. Terry (1986:163) menyatakan bahwa fungsi-fungsi manajemen tersebut merupakan serangkaian sub bagian tubuh yang berada di manajemen sehingga bagian-bagian tubuh tersebut dapat melaksanakan fungsi dalam mencapai tujuan organisasi. Untuk mencapai hal tersebut maka sekolah perlu kreatif mengembangkan bentuk-bentuk kemitraan dengan Dunia Usaha/Dunia Industri dalam rangka meningkatkan kompetensi lulusan 
yang dihasilkan. Kondisi ini didukung oleh pernyataan dari Sofyan (2000:29) yang menyebutkan bahwa: (1) Praktik di sekolah belum melibatkan persaingan mutu yang sesungguhnya, praktik di sekolah siswa belum bekerjasama dalam team work dan praktik di sekolah tingkat kesalahan pekerjaan belum diperhitungkan sebagai kerugian besar; (2) Pengalaman praktik di industri memberikan pengalaman yang membentuk kesiapan siswa di dalam memasuki dunia kerja secara nyata.

Suwati (2008:64) menyebutkan bahwa kegiatan kerjasama sekolah dengan Dunia Usaha dan Dunia Industri (DUDI) pada Sekolah Menengah Kejuruan yaitu melalui penerapan kerjasama sekolah dengan dunia kerja dapat diwujudkan dalam bentuk kelompok kerja Unit Produksi dan Jasa (UPJ) dan Biro Kerja Khusus (BKK) atau kelompok yang lainnya.

Dengan adanya hubungan antara sekolah dengan dunia usaha dan dunia industry akan menghasilkan suatu jalinan kemitraan yang dapat dilakukan untuk memperoleh masukan atau keuntungan bagi kedua belah pihak. Misalnya, pada pihak sekolah dapat meningkatkan kualitas lulusan yang siap didik untuk memasuki dunia industri maupun dunia usaha. Kemitraan antara sekolah dengan dunia usaha dan dunia industri merupakan wujud kesejahteraan bagi kedua belah pihak yakni meningkatkan mutu bagi dunia usaha dan meningkatkan kompetensi siswa yang terserap dalam dunia industri.

Adapun permasalahan dan tantangan yang terjadi di Sekolah Menengah Kejuruan (SMK) Negeri 1 Cihampelas Kabupaten Bandung Barat saat ini adalah sebagai berikut: (1) Animo masyarakat untuk mendaftarkan anak- anaknya di SMK Negeri 1 Cihampelas Kabupaten Bandung Barat tiap tahunnya cukup tinggi; (2) Keberadaan Dunia Usaha dan Dunia Industri jumlahnya terbatas atau sedikit; (3) Keterbatasan atau kurangnya jumlah guru produktif, sehingga dapat berimbas pada proses pembelajaran yang berlangsung; (4) Kurangnya kemitraan perusahaan, lembaga pemerintah, dunia usaha dan dunia industri dalam pelaksanaan pendidikan sistem ganda yaitu terjalinnya sinergi antara SMK dan industri.

Dari paparan di atas, maka dipandang perlu adanya penelitian tentang pengelolaan kemitraan antara sekolah dengan DUDI dalam rangka peningkatan mutu tamatan agar lulusan SMK memiliki jaminan keterserapan di pasar kerja. Penelitian ini difokuskan pada manajemen kemitraan sekolah dengan DUDI ditinjau dari perencanaan (planning), pengorganisasian (organizing), pelaksanaan (actuating) dan evaluasi (controlling), bentuk-bentuk kemitraan, faktor pendukung dan penghambat kemitraan, dan cara mengatasi hambatan dalam kemitraan tersebut dalam rangka meningkatkan kompetensi lulusan siswa.

Tujuan dari penelitian ini adalah: (1) Mengetahui manajemen kemitraan sekolah dengan Dunia Usaha dan Industri di SMK Negeri 1 Cihampelas Kabupaten Bandung Barat ditinjau dari perencanaan (planning), pengorganisasian (organizing), pelaksanaan (actuating) dan evaluasi (controlling); (2) Mengetahui bentukbentuk kemitraan sekolah dengan Dunia Usaha dan Dunia Industri (DUDI) untuk meningkatkan kompetensi SMK Negeri 1 Cihampelas Kabupaten Bandung Barat; (3) Mengetahui faktor yang mendukung kemitraan SMK Negeri 1 Cihampelas 
Kabupaten Bandung Barat dengan Dunia Usaha dan Industri; (4) Mengetahui faktor yang menghambat kemitraan SMK Negeri 1 Cihampelas Kabupaten Bandung Barat dengan Dunia Usaha dan Industri; (5) Mengetahui cara mengatasi hambatan dalam kemitraan SMK Negeri 1 Cihampelas Kabupaten Bandung Barat dengan Dunia Usaha dan Industri.

\section{Metode}

Jenis penelitian yang digunakan adalah penelitian deskriptif yang didukung data kualitatif. Menurut Cooper dan Schindler (2011:149) penelitian deskriptif adalah studi penelitian yang digunakan untuk menggambarkan fenomena terkait dengan subjek atau populasi untuk memperkirakan proporsi dari populasi yang memiliki karakteristik tertentu. Tujuan utama penelitian deskriptif menurut Neuman (2006:30) adalah untuk mendapatkan gambaran detail dari sebuah situasi, sekaligus menjawab pertanyaanpertanyaan seperti siapa, kapan, dimana, dan bagaimana. Dipilihnya jenis penelitian deskriptif, karena penelitian ini bertujuan untuk mendeskripsikan hal-hal yang terkait dengan manajemen kemitraan sekolah dengan dunia usaha dan dunia industri yang berjalan di SMK Negeri 1 Cihampelas Kabupaten Bandung Barat Miles \& Hubermann (1992:15) menambahkan bahwa penelitian yang menggunakan data kualitatif akan memunculkan data yang berwujud katakata dan bukan rangkaian angka. Data itu mungkin telah dikumpulkan dalam aneka macam cara (observasi, wawancara, intisari, dokumen, pita rekaman) dan yang biasanya diproses melalui pencatatan, pengetikan, penyuntingan, atau alih tulis.

\section{Hasil dan Pembahasan}

Penelitian yang telah dilakukan pada SMK Negeri 1 Cihampelas Kabupaten Bandung Barat tentang manajemen kemitraan sekolah dengan dunia usaha dan dunia industry (DU/DI) dalam meningkatkan kompetensi siswa menghasilkan beberapa hasil temuan penelitian sebagai berikut:

1. Manajemen kemitraan SMK Negeri 1 Cihampelas Kabupaten Bandung Barat dengan dunia usaha dan dunia industri ditinjau dari aspek perencanaan, pengorganisasian, pelaksanaan dan pengendalian/evaluasi dalam meningkatkan kompetensi lulusan.

\section{a. Perencanaan (Planning)}

Tahapan-tahapan dalam perencanaan dalam menjalin kemitraan dengan DUDI yang dilakukan oleh pihak manajemen SMK Negeri 1 Cihampelas Kabupaten Bandung Barat adalah:

1) Memasukkan unsur kemitraan sekolah dengan DUDI ke dalam visi, misi, dan tujuan sekolah

2) Merencanakan program kemitraan yang tertuang dalam rencana kerja sekolah (RKS) dan rencana jangka menengah (RKJM) empat tahunan

3) 3) Melakukan analisis internal dan eksternal sekolah

4) Perumusan struktur manajemen kemitraan dengan DUDI

5) Pemilihan dan pemilahan DUDI

6) Pengajuan kemitraan sekolah dengan DUDI

7) Melengkapi fasilitas untuk sarana kerjasama sekolah dengan DUDI 
Pada tahap perencanaan ini berbagai kegiatan yang berkaitan dengan kemitraan sekolah dengan DUDI dan telah dilaksanakan sebelumnya kemudian dievaluasi untuk menentukan langkah yang akan diambil selanjutnya. Kegiatan tersebut dilakukan melalui forum diskusi dari pihak manajemen sekolah maupun brainstorming dari pihak-pihak yang bersangkutan seperti guru, karyawan, siswa maupun dari DUDI. Hal lain yang menarik yang ditemukan adalah bahwa dalam melakukan analisis dan evaluasi terhadap kemitraan sekolah dengan DUDI ternyata hanya menggunakan kajian yang berdasarkan baik tidaknya kegiatan tersebut, sehingga jika dipandang baik maka kerjasama tersebut dapat dilanjutkan dengan beberapa pertimbangan yang menyertainya. Hasil temuan ini didukung oleh pernyataan responden sebagai berikut.

"Selama ini dalam
melakukan perencanaan untuk kegiatan yang berkaitan dengan DUDI hanya dilakukan evaluasi kegiatan setiap tahunnya, dan jika dipandang baik maka program tersebut akan dilanjutkan. Evaluasi dan pemetaan kegiatan tersebut tidak menggunakan analisis yang mendalam seperti analisis SWOT atau sejenisnya..."

Dari hasil penelitian tersebut nampak bahwa yang dimaksud dengan kegiatan analisis disini adalah kegiatan evaluasi dari kegiatan yang sudah berjalan bukan merupakan analisis adanya kekuatan, kelemahan, peluang dan ancaman yang dapat digunakan dalam menentukan bentuk atau program kemitraan yang dilakukan, seperti analisis SWOT misalnya. Tidak adanya kegiatan analisis tersebut akan memberikan dampak pada bentuk atau program yang dilakukan, yang sebagian besar akan berupa pengulangan programprogram sebelumnya yang dianggap baik. Belum ditemukan kegiatan yang sifatnya baru yang dihasilkan dari kegiatan analisis internal dan eksternal sekolah.

Pihak-pihak yang terlibat dalam perencanaan kemitraan sekolah dengan Dunia Usaha dan Dunia Industri. Pihak adalah Kepala Sekolah, Wakil Kepala Sekolah, Guru, Karyawan, Komite Sekolah, tokoh masyarakat setempat, Perwakilan DUDI. Jika hasil penelitian dari tahap perencanaan yang dilakukan di SMK Negeri 1 Cihampelas Kabupaten Bandung Barat tersebut dibandingkan dengan indikator keberhasilan dalam kisikisi penelitian dari aspek perencanaan yang berupa (1) menetapkan tujuan dan misi sekolah; (2) mengidentifikasi tujuan yang ingin dicapai sekolah; (3) menetapkan logis terukur dan akurat; (5) mengumpulkan bahan pertimbangan sebagai dasar merumuskan konten perencanaan; (6) memaparkan gambaran peluang yang ada; (7) memaparkan gambaran hambatan yang sudah dihadapi dimasa lalu yang mungkin 
akan dihadapi dimasa depan; (8) menyusun rencana kegiatan yang urut dan sistematis; (9) menyusun seluruh jenis pekerjaan yang dibutuhkan untuk mencapai tujuan; (10) menyusun panduan kerja yang dijadikan pedoman bersama; (11) membuat peraturan pelaksanaan kerja; (12) menyusun kerangka target dari setiap jabatan pekerjaan, maka dapat disimpulkan bahwa sebagian besar langkahlangkah perencanaan dari manajemen kemitraan yang dilakukan pada SMK Negeri 1 Cihampelas Kabupaten Bandung Barat sudah sesuai dengan indicator keberhasilan dalam kisi-kisi penelitian, sehingga dapat dikatakan baik.

\section{b. Pengorganisasian (Organizing)}

Menurut Terry dalam Hasibuan (2007:122) menyebutkan bahwa pengorganisasian adalah suatu tindakan mengusahakan hubungan-hubungan kelakuan yang efektif antara orang-orang, sehingga mereka dapat bekerjasama secara efisisen dan memperoleh kepuasan pribadi dalam hal melaksanakan tugas-tugas tertentu dalam kondisi lingkungan tertentu guna mencapai tujuan atau sasaran tertentu.

Pengorganisasian yang dilakukan dalam kegiatan kemitraan sekolah dengan DUDI adalah dengan membentuk tim atau pokja yang membidangi hubungan dengan industri dan memiliki tupoksi atau tugas pokok dan fungsi sendiri. Hal ini dilakukan agar manajemen dapat bekerja secara profesional dan menghindari adanya rangkap jabatan. Kepala sekolah bersama wakil kepala khususnya kurikulum dan humas/hubungan industri membentuk kelompok kerja (Pokja) yaitu Tim PKL/prakerin dan Tim BKK. Tim ini bekerjasama dengan bagian-bagiandi sekolah dan pihak DUDI untuk kelancaran dan terlaksananya kerjasama.

Berdasarkan

studi

dokumentasi yang diperoleh, bentuk-bentuk dari pengorganisasian kerjasama tersebut antara lain berupa dokumen atau arsip yang berupa SK Pembagian Tugas atau Pembentukan Tim Pokja atau panitia, struktur organisasi kemitraan SMK.

Jika hasil penelitian dari tahap pengorganisasian yang dilakukan di SMK Negeri 1 Cihampelas Kabupaten Bandung Barat tersebut dibandingkan dengan indikator keberhasilan dalam kisikisi penelitian dari aspek pengorganisasian yang berupa (1) perincian semua pekerjaan yang harus dilaksanakan setiap individu dalam mencapai tujuan; pembagian beban pekerjaan; (3) pengadaan dan pengembangan mekanisme kerja, maka dapat disimpulkan bahwa sebagian besar langkah-langkah pengorganisasian dari manajemen kemitraan yang dilakukan pada SMK Negeri 1 Cihampelas Kabupaten Bandung Barat sudah sesuai dengan indikator keberhasilan dalam kisi-kisi 
penelitian, sehingga dapat dikatakan baik.

\section{c. Pelaksanaan (Actuating)}

Upaya-upaya yang dilakukan dalam pengarahan atau pelaksanaan kerjasama SMK Negeri 1 Cihampelas Kabupaten Bandung Barat dengan pihak DUDI meliputi: (1) menyediakan sumberdaya manusia yang siap digunakan dalam bekerjasama dengan DUDI, baik itu guru maupun siswa dalam melaksanakan kerjasama dalam berbagai bentuk kegiatan. menyediakan finansial yang cukup untuk digunakan dalam pelaksanaan kerjasama, hal ini diambil dari sumber dana yang ada dan sesuai. (3) melengkapi fasilitas di sekolah yang dapat digunakan siswa untuk menunjang pelaksanaan kerjasama dengan DUDI.

Melalui studi dokumentasi diperoleh data, adanya perekrutan guru-guru maupun karyawan yang dilibatkan dalam pelaksanaan kemitraan sekolah dengan DUDI. Hal ini terlihat pada dokumen yang berupa SK Tim atau panitia dan struktur organisasi kemitraan SMK dengan DUDI.

Jika hasil penelitian dari tahap pelaksanaan yang dilakukan di SMK Negeri 1 Cihampelas Kabupaten Bandung Barat tersebut dibandingkan dengan indikator keberhasilan dalam kisi-kisi penelitian dari aspek pelaksanaan yang berupa (1) memberikan penjelasan kepada setiap orang yang ada dalam organisasi, mengenai tujuan yang harus dicapai; (2) setiap orang harus menyadari, memahami serta menerima dengan baik tujuan tersebut; (3) pimpinan menjelaskan kebijaksanaan-kebijaksanaan yang ditempuh oleh organisasi dalam usaha pencapaian tujuan; (4) setiap orang harus mengerti struktur organisasi; (5) setiap orang harus menjalankan peranan apa yang diharapkan oleh pimpinan organisasi dengan baik; (6) menekankan pentingnya kerjasama dalam melaksanakan kegiatankegiatan yang diperlukan; (7) memperlakukan setiap bawahan sebagai manusia dengan penuh pengertian; (8) memberikan penghargaan serta pujian kepada pegawai yang cakap dan teguran serta bimbingan kepada orangorang yang kurang mampu bekerja; (9) meyakinkan setiap orang bahwa dengan bekerja baik dalam organisasi tujuan pribadi orangorang tersebut akan tercapai semaksimal mungkin, maka dapat disimpulkan bahwa sebagian besar langkah-langkah pelaksanaan dari manajemen kemitraan yang dilakukan pada SMK Negeri 1 Cihampelas Kabupaten Bandung Barat sudah sesuai dengan indikator keberhasilan dalam kisi-kisi penelitian, sehingga dapat dikatakan baik.

\section{d. Evaluasi (Controlling)}

Evaluasi pencapaian dari pengelolaan kerjasama yang telah dilakukan antara SMK Negeri 1 Cihampelas Kabupaten Bandung 
Barat dengan dunia usaha dan dunia industri adalah (1) Melakukan penjaringan aspirasi siswa, (2) Menilai hasil presentasi siswa, (3) Mengevaluasi laporan tim terkait atau guru pembimbing terkait kemitraan sekolah dan DUDI, (4) Penyelarasan atau pembaharuan kerjasama antar kedua pihak.

Evaluasi tersebut dilakukan dengan metode brainstorming dalam forum rapat untuk menghasilkan suati kesimpulan dari hasil analisis. Selain itu evaluasi dan penilaian juga dilakukan melalui langkah-langkah berikut: melihat program yang terdapat pada MoU berjalan atau tidak, hal ini dilakukan dengan melihat hasil monitoring. (2) jika terjadi penyimpangan maka dilakukan koordinasi terhadap pihak DUDI dan dimusyawarahkan untuk kebaikan bersama. (3) jika terjadi kelebihan karena pihak DUDI memberikan nilai lebih baik, maka pihak sekolah memberikan reward kepada pihak DUDI tersebut (4) penyesuaian MoU terhadap DUDI yang telah memiliki peningkatan kualitas dan kerjasama.

2. Jika hasil penelitian dari tahap evaluasi yang dilakukan di SMK Negeri 1 Cihampelas Kabupaten Bandung Barat tersebut dibandingkan dengan indikator keberhasilan dalam kisi-kisi penelitian dari aspek evaluasi yang berupa (1) menentukan standar-standar yang akan digunakan menjadi dasar pengendalian; (2) mengukur pelaksanaan atau hasil yang telah dicapai; (3) membandingkan pelaksanaan atau hasil dengan standar dan menentukan penyimpang-an bila ada; (4) melakukan tindakan perbaikan, jika terdapat penyimpangan agar pelaksanaan dan tujuan sesuai dengan rencana, maka dapat disimpulkan bahwa sebagian besar langkah-langkah evaluasi dari manajemen kemitraan yang dilakukan pada SMK Negeri 1 Cihampelas Kabupaten Bandung Barat sudah sesuai dengan indikator keberhasilan dalam kisi-kisi penelitian, sehingga dapat dikatakan baik.

3. Bentuk-bentuk kerjasama yang dilakukan oleh SMK Negeri 1 Cihampelas Kabupaten Bandung Barat dengan pihak dunia usaha dan dunia industry. Bentuk-bentuk kerjasama sekolah dengan DUDI SMK Negeri 1 Cihampelas Kabupaten Bandung Barat antara lain: (1) telaah dan penyesuaian kurikulum dengan DUDI; pelaksanaan magang/PKL bagi siswa (Prakerin); (3) pelaksanaan magang/PKL bagi guru; pelaksanaan ujian kompetensi kejuruan (UKK); (6) program bakti masyarakat dan Corporate Social Responsibility (CSR) dari DUDI; (7) penyerapan lulusan oleh DUDI; dan (8) kunjungan industri; (9) pelaksanaan kegiatan bersama pada acara-acara tertentu.

4. Faktor - faktor yang menghambat kemitraan SMK Negeri 1 Cihampelas Kabupaten Bandung Barat dengan Dunia Usaha dan Industri, antara lain: (1) perbedaan orientasi sekolah dan DUDI, dimana jika sekolah lebih menitikberatkan pada masalah pendidikan, sedangkan untuk DUDI lebih kepada profit oriented; (2) keterbatasan jumlah DUDI yang ada 
disekitar sekolah; (3) jarak DUDI yang jauh dari sekolah; (4) kapasitas DUDI dalam menampung jumlah siswa magang; (5) ketidaksesuaian waktu dalam penyelenggaraan kerjasama sekolah dengan DUDI; (6) keterbatasan biaya yang diperlukan dalam rangka terjalinnya kerjasama; (7) keterbatasan sumber daya manusia dalam hal ini guru produktifumlahnya terbatas.

5. Cara mengatasi hambatan dalam manajemen kemitraan SMK Negeri 1 Cihampelas Kabupaten Bandung Barat. Langkah-langkah untuk mengatasi hambatan yang ada dalam manajemen kemitraan antara SMK Negeri 1 Cihampelas Kabupaten Bandung Barat dengan DUDI dilakukan dengan: (1) pemilihan dan penyamaan orientasi yang seiring tanpa mengesampingkan keuntungan untuk kedua belah pihak yang bekerjasama; (2) menjalin komunikasi mengenai penyesuaian waktu yang bisa seiring antara sekolah dan DUDI; (3) penggalian dana dari berbagai pihak yang terkait dengan kerjasama dari anggaran sekolah dan komite sekolah. (4) menjalin kerjasama dengan lebih banyak DUDI atau memperluas jaringan kerjasama; (5) melakukan rolling atau pergiliran siswa magang.

\section{Kesimpulan}

Kesimpulan dari penelitian ini adalah:

1. Manajemen kemitraan sekolah dengan dunia usaha dan dunia industri pada SMK Negeri 1 Cihampelas Kabupaten Bandung Barat ditinjau dari perencanaan, pengorganisasian, pengarahan/pelaksanaan dan evaluasi/pengendalian sudah berjalan dengan baik. Dalam hal perencanaan tidak ditemukan kegiatan analisis internal dan eksternal tetapi berdasarkan dari hasil evaluasi kegiatan yang telah dilaksanakan sebelumnya dan penelaahan layak tidaknya kemitraan tersebut dilanjutkan.

2. Bentuk-bentuk kemitraan sekolah dengan Dunia Usaha dan Industri di SMK Negeri 1 Cihampelas Kabupaten Bandung Barat sudah cukup bervariasi dan dilaksanakan secara rutin melalui kegiatan telaah dan penyesuaian kurikulum bersama dengan DUDI; pelaksanaan magang/PKL bagi siswa (Prakerin); pelaksanaan Ujian Kompetensi Kejuruan (UKK) dan kunjungan industri. Sedangkan bentuk kemitraan yang bersifat insidental meliputi kegiatan bakti masyarakat dan Corporate Social Responsibility (CSR) dari dunia usaha dan dunia industri (DUDI); penyerapan lulusan oleh dunia usaha dan dunia industry (DUDI) dan pelaksanaan kegiatan bersama pada acara-acara tertentu.

3. Faktor-faktor yang mendukung kemitraan sekolah dengan Dunia Usaha dan Industri di SMK Negeri 1 Cihampelas Kabupaten Bandung Barat antara lain adalah adanya kesamaan visi dan misi dari sekolah dan DUDI, kemampuan dan dukungan dari sekolah maupun DUDI, kemampuan dan dukungan dari komite sekolah serta ketersediaan sarana dan prasarana yang memadai.

4. Faktor-faktor yang menghambat kemitraan sekolah dengan Dunia Usaha dan Industri di SMK Negeri 1 
Cihampelas Kabupaten Bandung Barat antara lain adalah adanya perbedaan orientasi sekolah dengan DUDI, dimana jika sekolah lebih menitikberatkan pada masalah pendidikan, sedangkan untuk DUDI lebih kepada profit oriented, keterbatasan jumlah DUDI yang ada disekitar sekolah, jarak DUDI yang jauh dari sekolah, kapasitas DUDI dalam menampung jumlah siswa magang yang terbatas, ketidaksesuaian waktu dalam penyelenggaraankerjasama sekolah dengan DUDI, keterbatasan biaya yang diperlukan dalam rangka terjalinnya kerjasama dan keterbatasan sumber daya manusia dalam hal ini guru produktif farmasi yang jumlahnya terbatas.

5. Cara mengatasi hambatan dalam kemitraan sekolah dengan Dunia Usaha dan Industri di SMK Negeri 1 Cihampelas Kabupaten Bandung Barat antara lain dilakukan dengan pemilihan dan penyamaan orientasi yang seiring tanpa mengesampingkan keuntungan untuk kedua belah pihak yang bekerjasama, menjalin komunikasi mengenai penyesuaian waktu yang bisa seiring antara sekolah dan DUDI, menggali dana dari berbagai pihak yang terkait dengan kerjasama dari anggaran sekolah dan komite sekolah, menjalin kerjasama dengan lebih banyak DUDI atau memperluas jaringan kerjasama serta melakukan pergiliran atau rolling siswa magang.

\section{DAFTAR PUSTAKA}

Cooper, D.R., \& Schindler, P.S. 2011. Business research methods. 6th Ed.
New York: McGraw-Hill International Edition. p.100, 149.

Hasibuan, H.M., S.P. 2007. Manajemen sumber daya manusia. Jakarta: PT. Bumi Aksara.p.2, 68, 122

Ixtiarto, B. dan B. Sutrisno. 2016. Kemitraan sekolah menengah kejuruan dengan dunia usaha dan dunia industri (kajian aspek pengelolaan pada SMK Muhammadiyah 2 Wuryantoro Kabupaten Wonogiri). Jurnal ilmu pendidikan sosial. Vol 26, No.1, Juni 2016.

Miles, B.M. dan M.Huberman. 1992. Analisis data kualitatif buku sumber tentang metode-metode baru. Jakarta: UIP. p. 15, 20

Moss, J.R. 1984. Is vocational education ready for collaboration? collaboration: vocational and the private sector. Arlington. V.A. the American vocational association. p. 71-79

Murniati, A.R. 2005. Pemberdayaan sekolah menengah kejuruan melalui manajemen stratejik (studi tentang penyelenggaraan SMKN untuk menyiapkan lulusan sesuai dengan kebutuhan pasar kerja di Banda Aceh Nangroe Aceh Darussalam). Bandung: Program Pasca Sarjana Universitas Pendidikan Indonesia Bandung.

Neuman, L.W. 2006. Social research methods: quantitative and qualitative approaches. New York: Pearson Inc.

Prastowo, A. 2012. Metode penelitianpenelitian kualitatif dalam perspektif rancangan penelitian. Yogyakarta: Ar-ruzzmedia.

Sofyan, H. 2000. Kesiapan aspek kognitif dan psikomotorik siswa STM DIY. Jurnal kependidikan. No 1. April 2000, p.29-41. 
Sugiyono, 2005, Metode penelitian administrasi. Bandung: Penerbit Alfabeta.

Suwati. 2008. Sekolah bukan untuk mencari pekerjaaan. Jakarta: Pustaka Grafia.

Terry, G.R. 1986. Asas-asas manajemen. Bandung: Penerbit Alumni. p.163

Yulianto dan B.Sutrisno, 2014. Pengelolaan kerjasama sekolah dengan dunia usaha/dunia industri. Jurnal Pendidikan Ilmu Sosial, Vol. 24 No. 1, Juni 2014. p.23, 24, 33. 